\title{
A War in Words: James Joyce's Last Comedy (Finnegans Wake)
}

\begin{abstract}
From all accounts, Joyce is said to have claimed that World War II need never have happened if Europeans had read his last book, Finnegans Wake. Whether that is true or not, the book is intensely anti-authoritarian and anti-Fascist - not only in content, but also in its performative language. The rampant laughter heard and experienced throughout the text performs an effective deconstruction of any political, religious, moral, or philosophical ideology that explicitly or implicitly lays obstacles in the way of man's birthright to freedom. The humour of Joyce's poetic language entails an unmasking of unuttered premises of ideologies as well as a recognition of man's radical eccentricity and interdependence with the other.
\end{abstract}

Keywords: comedy, ideology, modernism, politics, satire

Rester sensible à ce comique, savoir rire encore devant telle ou telle manœuvre, cela pourrait devenir un devoir (éthique ou politique, si l'on veut) et une chance.

Derrida 1990, 90n1

\section{1 "Acomedy of letters"}

A critical treatment of laughter and joking is indispensable to the understanding of Joyce's last Work in Progress, which in many ways resembles a playful joke or "Acomedy [a comedy rather than an Academy] of letters" (Joyce 1975a, 425). ${ }^{1}$ In opposition to the bloodthirsty struggles taking place in Europe on account of high politics and bombastic ideologies, Joyce strives to deliver a humanistic and

1 Joyce planned to have published a critical essay on humour in Finnegans Wake in the sequel to Our Exagmination, but unfortunately it was never written (see Ellmann 1983, 613). Polhemus (1980, 294-338) has written elegantly and skilfully on the topic of laughter in Finnegans Wake; Benstock (1965, 108-163) has addressed farce and the ridiculous; Bonheim (1964) is preoccupied with Joyce's humorous anti-authoritarian attitudes; Mercier (1969) has shown how Joyce's anticlerical humour reflects an oral cultural tradition in Ireland that parodies and ridicules the representatives of the Church; and, finally, Lane (2002) covers the theme of laughter in Joyce's work generally. The ideology-critical aim of Joyce's poetics of laughter in the Wake is the specific topic of Boysen (2012). Here and elsewhere I have reworked and drawn on some of the argument and parts of that article.

2 Open Access. (C) 2021 Benjamin Boysen, published by De Gruyter. (c) BY-NC-ND This work is licensed under the Creative Commons Attribution-NonCommercial-NoDerivatives 4.0 International License. 
humorous alternative, representing an anarchistic magnum opus depicting the universal history of humanity. When Joyce, in all friendliness, was asked if he did not have anything better and more serious to do than to write Finnegans Wake, he answered: "Now they're bombing Spain. Isn't it better to make a great joke instead, as I have done?” (quoted in Ellmann 1983, 706). In another comment Joyce implied once that people would do better to read Finnegans Wake than to invade Poland (see Mercanton 1979, 249). In contrast to the masculine self-assertion of the ideologies marring Europe at the time, Joyce (in his own words) steps forth on the scene as "an Irish clown, a great joker at the universe" (Ellmann 1983, 703). Or, if we prefer to refer to the work itself, the author - who in one of his letters from 1926 signs himself "Jeems Jokes" (Joyce 1975b, 316) - is likened to "a veritable Napoleon the Nth, our worldstage's practical jokepiece and retired cecelticocommediant" (Joyce 1975a, 33). He is a mad (in popular culture, people gone mad are allegedly said to confuse themselves with Napoleon Bonaparte) and a megalomaniac ( $n$ is the mathematical notation for an infinite series) Irish comedian retired from the world at which he shakes his head. The grandiose and almost prophetic obscurity of the work is, in effect, counterbalanced by a self-ironic and subversive humour, which is why Joyce characterized it as "ma comédie nocturne" (Joyce 1957, 401). Joyce had a brilliant humoristic temper - for, as he archly confessed to Italo Svevo, "[n]ow and then I have a little fun" (Joyce $1957,155)$ - and this is nowhere more evident than in the case of his last work. Indeed, Finnegans Wake is a very funny book, and much speaks in favour of the view that this work designates a fluid space consisting of "great gas [Anglo-Irish, "great fun"] with fun-in-the-corner" (Joyce 1975a, 577).

Like the laughing heard at the carnival, Joyce's unassuming laughter does not originate from a pent-up, bitter feeling of privation, but rather from a surplus of life, which is not determined by class (or other) distinctions or differences only by excessive, transgressive, expansive, and inclusive affirmation. The person laughing is not burdened by formal respect, decorum, feelings of inferiority, or fear, but is reversely inspired and animated by a self-transcending and generous sense of self. The revolutionary potential inherent in the phenomenon of laughter is localized in an assumption of equality and freedom, which by nature has constituted a major problem for those interested in elevating themselves morally or politically above others. Joyce relentlessly targets such authorities that position themselves at the seat of the superego and demand subjugation and conservatism. As Helmut Bonheim asserts in Joyce's Benefictions, the author carefully appeals in favour of freedom and joy: "Man's birthright, Joyce argues repeatedly in Finnegans Wake, is to seek freedom from oppression of any kind" (Bonheim 1964, 127). This birthright is in many ways endowed as the right to laugh unhindered, because it is by means of laughter that chains are loosened or even forced open. Hence, the text 
pleas for the rights of the individual to be free, whereby it proves to be "anarchistically respectsful of the liberties of the noninvasive individual" (Joyce 1975a, 72). No one has the right to subdue the freedom of anyone. For this reason, it becomes an important task "to explique to ones the significat of their exsystems" (Joyce 1975a, 148), that is to say, to explicate the significance and value of an individual existence as a stepping out from a frozen and burnt-out system. In other words, it is high time that this system is replaced - not by a new one, but by an existence liberated from any system (exsystems).

\section{Joyce's risicide}

Apart from his debt to Giambattista Vico's cyclic theory of history from La Scienza Nuova, Joyce fetched his other important structuring principle, as well as the title, from the merry and burlesque Irish ballad “The Ballad of Tim Finnegan.” The ballad relates how Tim Finnegan, suffering from severe hangovers after a particularly wet evening, fell down from a ladder and broke his skull, and was proclaimed dead and carried home and watched over during his wake. However, after a scuffle breaks loose, whiskey (from Irish uisce beatha "water of life"; compare French eau de vie, Latin aqua vita, etc.) is accidentally spilled over him, and he consequently arises from the dead. The title thus contains a reference to a cycle (erection, fall, death, and resurrection) that includes the history of humans and humanity; but Joyce omits the genitive apostrophe to make the title plural as well as imperative: Wake up, Finnegans! Finnegans, wake! Accordingly, the refrain of the ballad rumbles friskily ("lots of fun at Finnegan's Wake"), which Joyce transmits as caricatured echoes such as: "patpun fun for all," "lotts have funn at Flammagan's ball," "lovesoftfun at Finnegan's Wake," "logs of fun," and "Fuddling fun for Fullacan's sake” (Joyce 1975a, 301, 321, 607, 512, 531). Finnegans Wake is actually a very funny book, though in its megalomanic tendency it is incredibly tendentious; yet the laughter and the outspoken disrespect make it exciting, dynamic - and wonderful.

This element of laughter is - in a manner that strikingly resembles the effect created by Joyce's text - excellently analysed by Baudelaire, who, in his De l'essence du rire, explains how laughter is twofold:

Le rire est satanique, il est donc profondément humain. Il est dans l'homme la conséquence de l'idée de sa propre supériorité; et, en effet, comme le rire est essentiellement humain, il est essentiellement contradictoire, c'est-à-dire qu'il est à la fois signe d'une grandeur infinie et d'une misère infinie, misère infinie relativement à l'Être absolu dont il possède la conception, grandeur infinie relativement aux animaux. C'est du choc perpétuel de ces deux infinis que se dégage le rire. (Baudelaire 1975, 532) 
Due to its fundamentally contradictory texture, which entails a highly hilarious potential, Joyce's Work in Progress is essentially human and liberating, and this is why I unreservedly agree with Umberto Eco when he states that "the force of the text resides in its permanent ambiguity" (Eco 1989, 67). The Falstaffian laughter of this "latterman! [Danish latter "laughter"]" (Joyce 1975a, 603) is distinguished by being entirely “ambiviolent” (Joyce 1975a, 518) inasmuch as it both includes feelings of infinite greatness as well as feelings of infinite insignificance. Yet laughter and ambivalence also entail a certain degree of aggression and even violence - as the word ambiviolent implies - directed towards the interpretive efforts of the reader, the hermeneutic authority of the writer, predecessors, and history, and finally towards language as such. This hostility or negativity against authorities is enacted in the words: "The war is in words and the wood [word] is the world" (Joyce 1975a, 104). For Joyce, man's perception of the world is given as a linguistic construction, and in order to create his own world he has to invent his own language, which he embarks upon in the Babylonian war of words that he effectively shakes into life in his "Shakespill” (Joyce 1975a, 161). This Shakespill (shake + Danish spil "game"), inspired by the spirit of Shakespeare, spills meaning out all over the place. Everything is transformed into something else, and the work is addressed to "every person, place and thing in the chaosmos of Alle [Danish "everybody"]" (Joyce 1975a, 118). It is simultaneously constructed as a chaos and a cosmos in which the only ruling principle is ambivalence: "The only faith that the aesthetics and metaphysics of the Chaosmos leaves us is the faith in Contradiction” (Eco 1989, 87). Inasmuch as the work contains “all thisorder” (Joyce 1975a, 540), it is extremely difficult to decide whether it designates an intelligible and rational semantic unity (this order) or, on the contrary, an amorphous, insane chaos (disorder).

It is this distinctive ironic style, which in Ulysses was "jocoserious" (Joyce 1986, 17.369), that Joyce takes ad absurdum in his succeeding work, which fundamentally consists of "prolonged laughter words" (Joyce 1975a, 600), that is, words describing one great conglomerate of histories, anecdotes, and a vast number of languages concentrated and fused in one great "collideorscape" (Joyce 1975a, 143). A good example of Joyce's "prolonged laughter words" could, for instance, be Shem's “Quoiquoiquoiquoiquoiquoiquoiq!” (Joyce 1975a, 195), which dissolves the foundation of the world into one big insistent question mark (French quoi) which celebrates the unceasing curiosity with which man tries to grasp the mystery of existence. Indeed, it is this awe and wonder - with which the fundamental mysteries of life and the world endow us - that in Finnegans Wake ensures that "All laugh" (Joyce 1975a, 249). Here, as Joyce remarked, the superior principle is given as: "in riso veritas" (Ellmann 1983, 703). Truth is revealed in laughter brought about by the infinite deferral of univocal meaning and reference, which 
instead are replaced by a perpetual ambivalence that tears letters, writing, and the transcendental logos apart in a loud roar of laughter: "writing and with lines of litters [litter + letters] slittering up and louds [loud + lots] of latters [Danish latter "laughter" + ladder]" (Joyce 1975a, 114). Hence, Joyce's poetics in the Wake is best characterized as a poetics of laughter, which at one and the same time contains pathos and bathos, sublime elevation and low, comic obscenity.

Instead of the sacred scriptures of the Jews, Moslems, and Christians, Joyce celebrates "our secret stripture” (Joyce 1975a, 293), which (it is implied) turns its back on the holy scriptures that deny and suppress the sexual and bodily aspect of our existence. In other words, Joyce's secret stripture manages to counteract the horrible consequences of the moral debasement brought about by inhibitions, shame, and disgust at our own nature as endorsed by the sacred scripture. Hence, Joyce's humane testament performs a moral striptease, where the low and dark sides of human existence - which under the yoke of morality and religion were repressed and demonized, thus giving rise to perversion and aggressive subjugation - lose their power as they are gradually acknowledged and made visible. This interest in our sensuous lowness, which Joyce untiringly depicts in its most embarrassing aspects, aims at and erects a fellow-feeling and solidarity originating from the fact that the solitude of the individual, suffering under the evermore alert and punitive supervision of morality, is splintered as the banality of the shameful is laid bare - thus depriving morality of one of its chief instruments for exercising power. The very fact of enlightenment regarding the things which morality bids abstinence from and silence about involves a liberating feeling of solidarity and community. This is one of the main features of Joyce's work - as George Orwell insightfully pointed out in the essay "Inside the Whale”:

\footnotetext{
He dared - for it is a matter of daring just as much as of technique - to expose the imbecilities of the inner mind, and in doing so he discovered an America which was under everybody's nose. Here is a whole world of stuff which you have lived with since childhood, stuff which you supposed to be of its nature incommunicable, and somebody has managed to communicate it. The effect is to break down, at any rate momentarily, the solitude in which the human being lives. When you read certain passages in Ulysses you feel that Joyce's mind and your mind are one, that he knows all about you though he has never heard your name, that there exists some world outside time and space in which you and he are together. (Orwell 1968, 495)
}

Hence, the naughty, dirty, embarrassing, and revolting functions of the body are humorously disclosed here - especially in connection with H. C. E. and his indiscretions, which are retailed in a vast number of versions. Embodying every one of us, Here Comes Everybody steps forth as "human, erring and condonable" (Joyce 1975a, 58; bolding added). 
Joyce's criticism of the Christian God in Finnegans Wake is not merely limited to questioning the metaphysical dimension of that religion, but also the very authority which this heavenly, paternal embodiment exercises. By doing so, Joyce seems to endorse the Russian anarchist Bakunin's (1814-1876) famous inversion of Voltaire's dictum: "if God really existed, it would be necessary to abolish him." The metaphysical collapse is brought to work by the blasphemous ridicule in which God (German Gott), to take just one example among others, is juxtaposed with contagious venereal diseases: "Gotopoxy” (Joyce 1975a, 386) - got a pox or God a pox (it is obviously of no small importance to bear in mind here that the final medical phase of syphilis often culminates in insanity). This manoeuvre runs parallel to the disrespectful metamorphosis of the religious supplicant's ejaculation (My Lord! My Lord!) to: “My Lourde! My lourde!” (Joyce 1975a, 299). In the new modern world, God is not only perceived to be a heavy (French lourde) burden; he is also impiously reduced to the abject state of shit (Danish lort). In other words, God (French Dieu) is quite simply deaf and dumb: "Dieuf and Domb" (Joyce 1975a, 149).

The Christian code supports the status quo of power, Joyce seems to imply, for, as the divine voice says in Finnegans Wake: "as it was let it be, says he!" (Joyce 1975a, 80). And by doing so, it consequently supports suffering and suppression, which is why Joyce ties it to one of the most repulsive and callous movements of modern history, namely Nazism. Finnegans Wake was published in 1939 at a time when the heinous atrocities and crimes of the regime were neither fully manifested nor fully known to the public; yet Joyce does not hesitate in his condemnation of "the Nazi Priers" (Joyce 1975a, 375), whose Fascist greeting (Sieg heil) is unequivocally rendered as: "Seek hells" (Joyce 1975a, 228). As a consequence of this, there is an extraordinarily hostile assault on Christianity (as the religion with which Joyce happened to be most familiar) when the latter is fused and amalgamated with the Nazi greeting to Hitler (Heil Hitler! Ein Volk, ein Reich, ein Führer): “heal helper! One gob [God], one gap, one gulp and gorger of all!” (Joyce 1975a, 191). One God, one leader - this is the very quintessence of Fascism and monotheistic religions, for as he himself says: "For thou shalt worship no other god: for the LoRD, whose name is Jealous, is a jealous God" (King James Bible, Exod. 34.14). One God, one leader, leading his people to victory over all others as an omnipotent army commander - compare the frequent invocation of Jehovah as the commander of army commanders (jhwh $s^{e} b \bar{a}$ 'ot) in the Old Testament - and one God, one leader, unconditionally demanding blood to be shed by everyone ("gorger of all") as well as blind submission to his will.

The monstrous sacrifices effectuated by the blessings of the representatives of Christianity throughout time are also satirically castigated in Finnegans Wake, where the Christian evocation of the Trinity - In the name of the Father, the Son, 
and the Holy Ghost - is tellingly rendered as: "In the name of the former and of the latter and of their holocaust" (Joyce 1975a, 419). The elevated holiness of Christianity is hence made synonymous with the benediction of genocide - for as it also says in the Wake, the Trinity amounts to "the fetter [German fett "fat, rich"], the summe [German "sum"] and the haul it cost” (Joyce 1975a, 153). In other words, the praxis of Christianity is an exercise in power, primarily interested in consolidating its supremacy by all means available; the hunt for profit or to get a fine haul is executed against the background of the howls of the suppressed and tortured - a praxis that will not refuse genocide (holocaust) if there is money in it. In addition, the Jewish and Christian expression for worshipping God, hallelujah (from Hebrew hallelu yah, meaning "praise Yahwe"), is reformulated by Joyce as "hilleluia, killeluia” (Joyce 1975a, 83), thus stressing how praising God, in practice, has been equal to killing in his name.

Joyce's merry and anti-authoritative human comedy is not limited to the sacrilegious ridicule of the Christian god, but is also directed against the political establishment and the state as such - for, as he told Georges Borach in a conversation: "As an artist I am against every state. [...] The state is concentric, man is eccentric. Thence arises an eternal struggle” (Ellmann 1983, 446). What Joyce, then, also strove to achieve with his art was a political vision in the form of socialism without Marx's revolutionary teleology and anarchism without violence. His political vision is therefore, to be more exact, a "politicoecomedy" (Joyce 1975a, 540). By means of puns, the self-proclaimed authority and dignity of the tyrants are reduced to their rightful ridiculed and scorned abjectness - as, for example, the Italian Fascist leader, Benito Mussolini, who was known under the pompous title "the Duke” (il Duce), but who, in Joyce's disrespectful and humanistic optics, is perceived instead as a joke, as "the juke" (Joyce 1975a, 162). It is through the war of language, and the succeeding laughter (Latin risus) following in its wake, that regicide is performed as "risicide" (Joyce 1975a, 161).

Art, pleasure, and love stand in a certain opposition to the state's engagement with "power, politics, and money." As an extension of this, Joyce explained why it simply was not possible for him to work as an artist in England: "I decided that I could never have become a part of English life, or even have worked there, for somehow I would never have felt that in that atmosphere of power, politics, and money, writing was not sufficiently important" (Power 1974, 64). The reader only has to direct his attention to the Wake itself to find confirmation of the fact that the book explicitly defines itself in opposition to English mercantilism and common sense: "You will say it is most unenglish and I shall hope to hear that you will not be wrong about it" (Joyce 1975a, 160). In addition, England, the "nation of shopkeepers" (Adam Smith) and conquerors, is understood as "Englend" (Joyce 1975a, 170), that is, as the nation that has brought much misery (German Elend) 
about. The deconstruction of the English language is, as a matter of fact, equal to the author's violent assassination of the idea of the unity of the British Empire: "having murdered all the English he knew" (Joyce 1975a, 93). To say it "inplayn unglish [and not plain English]" (Joyce 1975a, 609), the poetical gesture of Finnegans Wake consists in a playing (not plain) negation (cf. the prefixes in- and un-) of English linguistic and ideological structure (as Joyce saw it).

With Beryl Schlossman, in sum, we can say that "English becomes a series of enunciations that are undermined, pulverized, and pluralized by the lexical and syntactic presence of other languages. English as such begins to disappear into fragments. Its apparent unity has been invaded" (Schlossman 1985, 162). Joyce's idiomatic language marks a revolt against or violence towards the unifying function of everyday language that consolidates a cultural, national, and political centralization. Joyce's war on the English language is not merely aggressive, for by its transgression it makes way for openness and hospitality, which is why he, in one of the notebooks for Finnegans Wake, writes: "JJ's [James Joyce's book] not hell open to Christians but English open to Europeans" (Joyce 1978, 13). And the liberating, inclusive, as well as welcoming gesture of his dissolution of English is furthermore evidenced when much of the sternness of old Anglo-Saxon English (German Altenglisch) is invested with laughter (German lachen) "wherever my good Allenglishes Angleslachsen is spoken" (Joyce 1975a, 532; bolding added). Joyce replaces the ruling discourse of those in power with his own syntax, "sintalks" (Joyce 1975a, 269), which inscribes the marginalized and repressed (sin) into the very core of authority, from which sin talks freely now. Hence, Joyce's writing works as a linguistic virus that in its capacity as sintalks goes directly into the veins of authority, which henceforward is seriously weakened by this infection that thus fights the enemy on his own ground.

In an echo of the sentence engraved on the monument to the Irish champion of liberty Charles Stewart Parnell (which is to be found at the end of Dublin's O'Connell Street), and which is taken from a speech he gave in Cork in 1885, we read: "No mum has the rod to pud a stub to the lurch of amotion" (Joyce 1975a, 365). Parnell's words were: "No man has the right to put a stop to the march of a nation." The sentence is, in Joyce's reformulation, more general, inclusive (even cosmopolitan), and, in a sense, non-political, since it emphasizes how the lurch of emotions is immune to the censorship of tyrants and oppressors. Hence, a common community is not defined in terms of nationality or political orientation, but rather by a common emotional and existential lot; and this emotional community primarily consists in love. It is, that is to say, a community in which no one has greater rights than others where the feelings of others are concerned, which consequently makes this community more democratic and inclusive (cf. the transformation of man to mum). 


\section{Conclusion}

Joyce's self-declared war on language in the Wake (cf. Joyce 1957, 237) effectively fuses the poetic with a hilarious socio-ideological critique. The negativity and linguistic violence of this manoeuvre is not merely negative and destructive, for, as Julia Kristeva has argued in her book on the avant-garde of the nineteenth finde-siècle (Mallarmé and Lautréamont), poetic language contains a revolutionary potential through its effects of negativity, striving “à remodeler le dispositif signifiant historiquement accepté, en proposant le représentation d'un autre rapport aux objets naturels, aux appareils sociaux et au corps propre" (1974, 116; emphasis in original). That is to say, Joyce's new language thus paves the way through its linguistic ridicule and deconstruction of the established, repressive power-ideologies - for an opening up of the new: a dynamic potentiality stressing freedom, love, and solidarity. As Jean-Michel Rabaté has aptly shown, it is in this manner that Joyce succeeded in unleashing a veritable poetics of hospitality: "As he hoped, individual artistic toil might redeem and perhaps heal the diseases of the collective spirit such as xenophobic nationalism, fascism, and religious bigotry. The new language should in the end create a new and different reading practice strong enough to subvert those ideologically reactionary values that are still latent in the old Sittlichkeit" (2001, 82). This new language of hospitality is erected against the powerful background of laughter and the linguistic negation of what is proper, thus disclosing how a sensitivity to bathos, comedy, and negativity - the ability, that is, to laugh freely at this or that articulation of power entails an ethical, amorous, and political opportunity or even necessity.

In this work, Joyce does not introduce us to a Divina Commedia (with a love of the divine), but rather to a Commedia umana (with a love of the human). In other words, the author steps forth as "Undante umoroso" (Joyce 1975a, 269), that is, as an author that, to some degree, shares Dante's amorous epiphany (amoroso being the adjectival derivative of Italian amore "love"), but with the reservation that this vision of love should, by contrast, be firmly set on celebrating the dynamic existence of biological life instead of a static beyond. To be more precise, he endorses a humorous (Italian umoroso) love of humanity full of humour, which is why he does not count himself to be a Dante (French un Dante), but rather the very opposite, a non-Dante (unDante) who ridicules and deconstructs "the spiritual-heroic refrigerating apparatus, invented and patented in all countries by Dante Alighieri" (Joyce 1992, 275). In contrast to the heroic, idealistic, and metaphysical love which petrifies human existence, Joyce expresses an "Amousin [amusing + French amour] thought" (1975a, 107), whose "huemoures [humours + amours]" (102) highlight the intimate connection of humour and laughter with love. Finnegans Wake is consequently the result of a "generous comicsongbook soul” (Joyce 1975a, 380). 
The special attention paid to the comic is consequently equivalent to a special sensitivity to love, since both of these phenomena originate in a certain concern with temporality, heterogeneity, and contingency, which are affirmed and conquered at one and the same time through their funny, yet passionate moves: "But just because there is always a hidden pain in humor, there is also a sympathy" (Kierkegaard 1992, 553).

\section{Works cited}

Baudelaire, Charles. Euvres complètes. Vol. 1. Paris: Gallimard, 1975. Bibliothèque de la Pléiade.

Benstock, Bernard. Joyce-Again's Wake. Seattle: University of Washington Press, 1965. Bonheim, Helmut. Joyce's Benefictions. Berkeley: University of California Press, 1964.

Boysen, Benjamin. “Joyce's Politicoecomedy: On James Joyce's Humorous Deconstruction of Ideology in Finnegans Wake." Joyce Studies in Italy 13 (2012): 93-103.

Derrida, Jacques. Heidegger et la question. Paris: Flammarion, 1990.

Eco, Umberto. The Middle Ages of Joyce. Trans. Ellen Esrock. London: Hutchinson Radius, 1989. Ellmann, Richard. James Joyce. 1st rev. ed. Oxford University Press, 1983.

Joyce, James. Letters: The Letters of James Joyce. Vol. 1. Ed. Richard Ellmann and Stuart Gilbert.

London: Faber and Faber, 1957.

Joyce, James. Finnegans Wake. New York: Penguin, 1975a.

Joyce, James. Selected Letters of James Joyce. Ed. Richard Ellmann. New York: Viking Press, 1975b.

Joyce, James. Finnegans Wake: A Facsimile of Buffalo Notebook VI.B.21-24. Ed. Danis Rose. New York: Garland, 1978.

Joyce, James. Ulysses. Ed. Hans Walter Gabler. New York: Random House, 1986.

Joyce, James. A Portrait of the Artist as a Young Man. London: Penguin, 1992.

Kierkegaard, Søren. Kierkegaard's Writings. Ed. and trans. Howard V. Hong and Edna H. Hong.

Vol. 12.1. Princeton: Princeton University Press, 1992.

Kristeva, Julia. La révolution du langage poétique. Paris: Éditions du Seuil, 1974.

Lane, Jeremy. “James Joyce's Book of Laughter and Forgetting." A History of English Laughter.

Ed. Manfred Pfister. Amsterdam: Rodopi, 2002. 137-152.

Mercanton, Jacques. "The Hours of James Joyce." Portraits of the Artist in Exile: Recollections of James Joyce by Europeans. Ed. Willard Potts. Seattle: University of Washington Press, 1979.

Mercier, Vivian. The Irish Comic Tradition. Oxford: Oxford University Press, 1969.

Orwell, George. The Collected Essays, Journalism and Letters. Ed. Sonia Orwell and Ian Angus.

Vol. 1. London: Secker \& Warburg, 1968.

Polhemus, Robert M. Comic Faith. Chicago: University of Chicago Press, 1980.

Power, Arthur. Conversations with Joyce. Ed. Clive Hart. London: Millington, 1974.

Rabaté, Jean-Michel. James Joyce and the Politics of Egoism. Cambridge and New York:

Cambridge University Press, 2001.

Schlossman, Beryl. Joyce's Catholic Comedy of Language. Madison: University of Wisconsin Press, 1985. 
Benjamin Boysen (b.boysen@sdu.dk, b. 1975), associate professor in the Department of Comparative Literature at the University of Southern Denmark, is author of The Ethics of Love: An Essay on James Joyce (Odense: University Press of Southern Denmark, 2013). Recent publications include "The Embarrassment of Being Human: A Critique of New Materialism and Object-Oriented Ontology," in Orbis litterarum 73.3 (2018), and "Poetry, Philosophy, and Madness in Plato," in Res Cogitans 13.1 (2018). 
